\title{
Sustainable Urban Planning and Tourism Management
}

\author{
Secil Gul Meydan Yildiz (Corresponding author) \\ Faculty of Engineering and Architecture, Department of City and Regional Planning, \\ Yozgat Bozok University, Erdogan Akdag Campus, Yozgat, Turkey \\ ORCID: https://orcid.org/0000-0001-9869-4159 \\ E-mail: secil.meydan@bozok.edu.tr
}

\author{
Hayriye Sengun \\ Faculty of Economics and Administrative Sciences, Department of Political Science and Public \\ Administration, Bayburt University, Bayburt, Turkey \\ ORCID: https://orcid.org/0000-0002-1899-8329 \\ E-mail: hsengun@bayburt.edu.tr
}

\begin{abstract}
Tourism, which is a significant opportunity for increasing competitiveness, becomes an important aim of development when it is integrated with sustainability and protectionism principles. The association of the tourism sector, which has developed all over the world with the globalization process, with the conservation policies and environment centered approaches is a crucial practice in terms of protecting universal values. However, this process has to be integrated with the management and planning policies. Conservation and sustainability principles should be the fundamental strategy of the local actors in the tourism planning for the protection and promotion of social values. In this way, economic development goals may be integrated with the protection policies. This study aims to make visible the necessity of an environment- centered perspective in tourism management and its contribution to sustainable development. In this study, it is put forward that the tourism principles which are planned with an environment centric sense of management, prevents the spatial problems and sprawl to emerge in consequence of the decisions and applications regarding the use of land and the role thus the importance of these principles in the sustainable development process are underlined.
\end{abstract}

Keywords: Tourism Management, Sustainability, Anthropocentrism, Environment-Centrism.

DOI: $10.7176 / \mathrm{JSTR} / 5-2-09$

\section{Introduction}

World-scale sectoral transformations within the globalization process enforce the differentiation and transformation of the areas according to the complex cultural processes. Technologic developments created by the information age and environmental, economic and cultural problems borne by these developments raised the rank of the strategy of returning to organic, natural and environment friendly life for economic development. The spatial application of sustainable tourism policies maintains both the development of the tourism-centered economies and avails the protection and transmission of the historical, archeological, cultural and natural places to the next generations. Increasing the investment and support of the tourism is an important vision for the protection and sustention of cultural heritages of the countries. Tourism sector covers the social, economic and environmental dimensions of the sustainable development. The balance between protection and economic development can be maintained by enacting the sustainable tourism policies. This process is enriched by the anthropological and natural values of the societies and gets importance with the adoption of the tourism by the local residents as a life style. Local factors may have positive and negative effects on tourism depending on the sociocultural, economic and environmental structure as on the other sectors. Consequently, it is important that tourism investments are coherent with the life styles of the local residents, physical structure and the civil features of the area.

The success of the tourism administration depends on the viewpoint of the local actors. The tourism

78 | P a g e

www.iiste.org 
administration designed with a human-centered point of view provides profitability for the short-term and destructs the environment. As a result, the implementation of a sustainable tourism sector can be realized by a planning and application of tourism administration which is designed with an environmentcentered point of view. On the other hand, the assessment of the tourism sector only as a source of income raises the destruction of the sector on the environmental values. The balance between urban administration and tourism is as important as the balance between development and protection. If the urban development related on the tourism is assessed as an economic development, the decay of the environmental values is unavoidable. The protection of the residential areas from rental pressures and environmental values can be provided by tourism administration designed on sustainability based protection policies.

The sustainable tourism policies providing balance on the social, economic and environmental dimensions are based on the conservation and survival of the residential areas by branding them as tourism cities. The assessment of the tourism capacity of the area related with the economic and environmental dimensions, and development of the action plans according to these structures depends on the efficient participation of the local residents, civil society organizations and local governments. The tourism activities maintaining economic sustainability creates a consciousness for protection of the cultural and natural values in the local society. In addition, the branding process of the cities on the national and international level created by tourism may lead the consumption of the ecological values with a rent orientation. Especially, the coordination of local administrations and civil society organizations for the residential areas with productive agricultural lands, forests and shores. Otherwise the pressure groups and land speculators will be active in decision taking processes against proenvironment decisions. The greed and selfish activities for providing more profit and creating new residential areas disrupt historical and natural values. The tourism resolutions without the rational and environmental basis create several environmental problems in the cities without sufficient infrastructures. In addition, the cultural interaction practiced within the travelling and accommodation processes can lead breaking from the traditional behavior and the threat of depletion of the local culture. Among the services sectors tourism has great importance for traditional practices and for the economic development of the related region as well. The local actors can play important roles in materialization of the strong sides of the tourism sector. The analysis of the cities and citizens and the environment-centered regulations by the local actors are required for the implementation of the sustainability.

\subsection{Concept of Tourism and Tourism Management}

The tourism activities are defined as leaving the residential areas and utilization of the free times for short term for several purposes like travelling, vacation, entertainment. These activities vary and develop through the need and curiosity for exploring and learning without any time or spatial limitation and integrated with 20th century, environment consciousness and technology (Türker, 2014: 81; Doğanay, 2001: 15).

Today, although the mass telecommunication media are advanced, the demand to get familiar with and have information on the different cultures can be satisfied by the assessment of that culture with the relevant environment (Kozak 2012b: 109). Consequently, globalization and environment friendly approaches increased the diversification of the tourism sector. Especially, the introduction of the places with different cultures and natural values through information technologies trigger the enthusiasm for visiting and observing such places. This process, leads initially massive diversification and later individual diversification on the private interest develops the consciousness of the local residents (Kozak Akoğlan et al. 2013: 11). Tourism was conceptualized first by Guyer-Feuler in 1905. Guyer-Feuler defined tourism as “...A phenomenon unique to modern time which is dependent on the people's increasing need for a change and relaxing, the wish of recognizing the beauties of nature and art and the belief that nature gives happiness to human beings and which helps nations and communities' approaching to each other thanks to the developments in commerce and industry and the communication and transportation tools' becoming excellent" (Çoruh, 1979: 8). The demand for escaping from social and psychological problems lead by rapid urbanization, population growth, industrialization and environmental pollution increases individuals' need for relaxing in natural environment. These demands support the tourism by privileging environment.

The curiosity for the natural and genuine with the intermediation of the tourism can provide opportunities for the utilization of many traditional practices, handcrafts which are to be extinct or living areas which 79 | P a g e 
belong to the ancient times and are to sink. Human beings started to move away from massive urbanization and towards the traditional with the effect of environment- friendly approaches supporting the development of human-nature relations and international agreement. The demand for moving away from the negative effects of the urbanization in leisure times, drives people towards the areas which integrated with the natural environment, plain and conserved the rural features (Eralp, 1983: 19-20). Tourism maintains balance between economic and historical values (Doğan and Y1ldı, 2007: 155). Consequently, the investments initiated through tourism provide income and employment both for the developed and developing residential areas (Avcikurt, 2007: 35-37). The identity, natural and historical values can be conserved without any distortions if these investments would be planned in accordance with the environment-friendly approaches aiming the satisfaction of living requirements. At this point, the ethical positioning of the city administration on investment and resolutions is important. In case of a divergence between the expected economic effects of tourism investments such as income effect, employment effect and enhancing investments and outcomes, the natural areas can be utilized in other sectors or different implementations which lead to ecological degradation can be planned (Avcikurt, 2007: 47). The relation between sustainability and tourism emerges at this point. The conservation of historical, cultural and environmental values maintains sustainability of the tourism activities directly (Kozak, 2012a: 4). Because of this reasons, the adoption of the sustainability principles in tourism sector supports both conservation of such values and development of the tourism sector. Especially, rapidly increasing environmental degradation, climate change, extinct species, the loss of the authenticity of historical, monumental and urban values made the sustainable global development an interdisciplinary target.

\subsection{Sustainable Tourism}

The concept of sustainability born at the Stockholm Conference (1972), recognized officially and came into our lives by Our Common Future Report (1987) is the cluster of principles which target the utilization of the environmental, historical and cultural beauties not only by the generations of today but also by the next generations (Meydan Y1ld1z, 2016: 22). Sustainable development is composed of intergenerational equality, social justice and cross-border responsibility dimensions. The sustainability concept providing the insurance of the future covered the tourism sector which develops rapidly and is not affected from the global crises. The principal of sustainability targeting the balance between ecology and economy, provides a balance between protection policies and tourism investments as well. The possibility that any distortion on the environmental and cultural values has negative spillovers on the economy of the city explains the need for sustainable tourism policies (Doğan, 2012: 12). The decline in the touristic interest against the loss of the environmental, historical and cultural values and beginning of the material losses as a result stimulates the consciousness of the society for conservation. Tourism is an important sector, rapidly developing with its market volume and economic potential (Kozak Akoğlan et al. 2013: 7), supports development and growing and diversifying since the 19th century (Avc1kurt, 2007: 105). The progress of sustainable development policies diversifies the economic effect of the sector limited with the "sea, sun, sand (coastal tourism) and targeting only the coastal regions.

Since tourism starts with an economic decision on the utilization of the leisure time and savings and is composed of several socio-economic decisions with economic components such as investment, consumption, employment, exportation and public revenues, the common component of these decisions is the environment (Kozak, 2012a: 10). The alternative employment activities which support the sustainability of the tourism sector such as culture tourism, nature tourism, agro-tourism, tableland tourism and history tourism are the products of natural or physical environment which support the development of the cities, regions and countries (Doğan and Y1ldız, 2007: 159-161). Provision of the sustainability of the components and wealths without disturbing their quality and quantity is called sustainable tourism (Gündüz, 2004: 60). Sustainable urban development should be composed of the decisions which serve not only for the tourism but also to the whole economy and which adopt the principle of environmental and socio-cultural dimension of the sustainability (Padin, 2012: 510-513). In addition, it is the planning method which provides the qualified, rational and productive utilization of the tourism resources, supports the utilization of renewable energy resources, targets the elevation of the quality of ecosystems and human life, takes the next generations into consideration, targets economic income by preserving and without consuming, polluting and destroying (Avc1kurt, 2007: 103-110).

It is unavoidable to face with the demographic change lead by the economic developments borne by $\mathbf{8 0 |} \mathrm{P}$ a g e 
tourism. The diversification of the employment opportunities depending on the touristic demand of the places which have tourism potential leads increasing resident population. The city administration should plan the outcomes of tourism by taking the demographic features into consideration. In addition the touristic demands developing and diversifying in accordance with the requirements of the day such as accommodation, transportation, infrastructure, vacation and entertainment may require new employment areas and land utilization. Ignorance of rational and environment friendly policies in spatial decisions may turn the tourism activities which is assessed as an economic opportunity to the source of several civil, environmental and biological problems. The eager to profit more from tourism may lead depreciation of the genuine values and identity of the city which compose the brand of the city, by leaving these values and identity to be the subjects of density, pressure and destroying through new construction terms and activities, transportation and infrastructure legislation (Doğan, 2012: 36). The sustainability principles should be adopted in the administration plans and transferred the tourism policies. The applicability of these principles depends on the vision of the actors who take role in administrative processes about the relation between human-environment. These visions are classified as anthropocentrism or eco-centrism.

\section{Sustainable Tourism Management and Environmental Approaches}

The linking of the tourism with sustainable policies and application of the spatial decisions in accordance with these linkages depend on the environment and participation consciousness of the local actors. In other words, the success of the tourism sector is highly correlated with the philosophical approach adopted. The development of the local actors' activities in line with the environmental protection and tourism balance is shaped by the visions adopted in administrative processes. It will be suitable to detail this process by the anthropocentrism (human-centered) and environment-centered (eco-centrism) approaches. By this way, it will be clarified that tourism administration is not only a process limited with the areas to visit but is an interdisciplinary activity and administrative approach.

\subsection{Anthropocentric (Human-Centered) Approach In Sustainable Tourism}

The societies inclined to the consumption, design their power to maintain the sustainability of their economic development by competitive policies. This approach creates a human-centered administrative understanding which prioritize the maximum utilization of the nature, creating capital and accumulating wealth. At the same time it leads the assessment that nature is a vehicle under the human command. Anthropocentrism is a way of thinking which assumes human being as the center of all values, prioritizes human interest on all values, puts human being at the center of the universe and positions all other things according to the human being (Keleş, 2013). Anthropocentric thought is an "philosophical approach which assumes the existence, interests and concern for the future of human being as the starting point" (Mengi and Turan, 2016b: 169). In this approach, nature and the creatures other than human are valuable as far as they provide utility to the human being and for the interest of the current and next generations, human should dominate the nature. According to the anthropocentrism, human being owns a special position in nature and is the commander of nature. Consequently, the creatures other than human being do not have any rights on the nature. All living and nonliving beings are means to maintain the continuity of the human species and serve for the targets and interests of human being (Keleş, 2013).

According to the tourism administration vision based on the human-centered approach, all creatures in nature are created for the human being, consequently the only value is human. Furthermore, human do not have any responsibility about other creatures (Kılıç, 2013: 162). Hence, the main point according to the human-centered approach is the satisfaction of lively requirements of the human being. The limited pain-centered approach which is the first step diverging from human-centralism and evolving through environment-centered approach has been derived from the word 'pathein' which means feeling the pain in Greek. Jeremy Bentham (1748-1832) is accepted to be the first representative of this thought (K1lıç, 2013: 162). The role of the human being who is in emotional contact with the domestic animals is important in the development of the limited living being-centered approach. This is the approach to protect animals, to heal their living spaces and to avoid all kinds of behaviors which can disturb them and pain. Although this approach is an important step towards the development of animal rights and avoids behaviors which disturb them, since it focuses only on the domestic animals, it leads segregation between the animals (Kılıç, 2013: 162).

According to the living being-centered approach derived from the 'bois' word from Greece, each living $\mathbf{8 1} \mid \mathrm{P}$ a g e 
being on the globe is a part of the chain within the ecological balance and is in an effort to maintain the survival of its species and keep alive. Consequently, all living beings own equal rights. The living beingcentered approach advocates that human being is not the only value in the nature and cancels the segregation between human beings, animals and plants. According to the tourism understanding based on the living being-centered approach each living beings is an equal partner of the life on the globe. Albert Schweitzer and Paol Taylor advocated that all species are equal and own equal rights, but there are other approaches which advocate that there is a hierarchy between the living beings, especially living beings own values and thinking capacity may own some exemptions (Kılıç, 2013: 171). Because in this approach, there is no solution formulated for the conflict of interest between human beings and other living beings. However, the living being-centered approach succeeded to overcome the dilemmas of the limited living being-centered approach and diverge significantly from anthropocentric approach.

\section{2. Environment-Centered (Eco-Centric) Approach in Sustainable Tourism}

The eco-centric approach was derived from the word 'holon' meaning the whole in Greek and has been used as holistic-environment meaning. The accumulation of the environmental problems created by the human dominance day by day leads the development of the environment-centered way of thinking. Ecocentric approach values nature for its own sake and, therefore, judges that it deserves protection because of its intrinsic value (Gagnon Thompson and Barton, 1994: 149). According to the environmentcentered way of thinking, the main reason for the emergence of environmental problems is that the efforts to understand nature and to turn people towards itself change over time and leave their place to the understanding of dominating nature and the solution to the problem is to understand that nature is an inseparable part of human species existence (Görmez et al., 2012: 724,734). According to the environment-centered way of thinking, living or non-living things are components of the global ecosystem. While the living pain-centered approach covers only the living creatures, the environmentcentered approach covers the nonliving things as well. The environment-centered approach focused on the environment as a whole covers living or nonliving and natural or artificial all ecological values. It offers a basic approach for the applicability of sustainable tourism policies with these features.

According to Leopold, as a result of the egalitarian ecosystem understanding, natural resources are parts of the whole composed by living creatures and own value (Mengi and Turan, 2016a: 76-79). Environment-centered view approaches to the technology with doubt; it assumes that high technology increases environmental problems but the technologies coherent with the nature avoid any disruption on the natural balances. Because ecocentrics see nature as worth preserving regardless of the economic or lifestyle implications of conservation and for ecocentrics, nature has a spiritual dimension and intrinsic value that is reflected in their experiences in nature and feelings about natural settings (Gagnon Thompson and Barton, 1994: 150). According to the environment-centered point of view, technological development which is coherent with the nature will make the production types and human activities coherent with the nature as well. The adoption of sustainable tourism policies as an administration understanding can be maintained by the acceptation of the environment-centered point of view as a life style. It is obvious that the protection and introduction of local resources can be realized by the plans designed according to the holistic understanding that the relation between environment and nature is intact. Otherwise the continuity of the sustainable tourism policies coherent with the development process is impossible. Human centered tourism policies may lead resolution which will damage the environment in the long run. Only the environment centered point of view which accepts the unity and equality of human and nature can provide the protection of the touristic values by the local residents.

\section{Sustainable Tourism Principles and Implementation}

Sustainability and conservation policies are among the most important aspects of OECD, EU and UN tourism policies. OECD Tourism Committee, which was established in 1961, analyzes the policies and management processes that affect the development of tourism. OECD aims for the tourism to become a competitive and sustainable sector in the economic development process (http://www.kalkinma.gov.tr, access date: 23.12 .2018 ). At the same time, OECD specifies that tourism has to be managed by active, innovative and integrated policies and defends that countries have to develop common tourism tendencies (http://www.oecd.org/industry/tourism/Tourism2016Highlights_Web_Final.pdf, access date: 19.12.2018).

OECD emphasizes that a conservation oriented tourism management facilitates the transformation of 82 | $P$ a g e 
functions and establishes a management system which may be more easily adaptable, flexible, innovative and reproducible. EU deals with the tourism management multidimensionally (İnceoğlu, 2005, http://www.anayasa.gov.tr/files/pdf/anayasa_yargisi/anyarg22/sibel.pdf, access date: 19.12.2018). However, with respect to tourism, EU does not pursue a policy that is legally binding (Karakuş 2003: 3). EU handles tourism management together with a lot of issues such as occupational safety, health, environment, regional development, consumer rights, employment, free circulation, taxation, cultural and educational research etc. (Arslan, 2014: 435-436). In EU studies, sustainability is also the main element of tourism policy just like in urban and environment management. Specifying the factors that affect tourism in detail and transferring this process to management policies with the purpose of protecting and developing the natural and cultural environment are emphasized. The productivity, competitive power and environmental conservation are indicated as primary goals in the international studies. While limiting the domain of the central government with information sharing and guidance, EU common tourism policy assigns more missions to local governments and private sector (Arslan, 2014: 437). Local governments are the key actors in evaluating and increasing the economic benefits and costs of tourism (https://ec.europa.eu/growth/sectors/tourism/offer_en, access date: 19.12.2018).

Sustainable tourism is assessed as an important economic factor that has a comprehensive effect on the employment and social development in United Nations. UN Environment Program and World Tourism Organization defined 12 targets for the sustainable tourism (http://www.unep.fr/shared/publications/pdf/DTIx0592xPATourismPolicyEN.pdf., access date: 20.12.2018). These are 1) Economic Sustainability; Maintaining the sustainability and competitiveness of the tourism destinations and firms in order to provide the continuity of their success, creation of utility and growth. 2) Local Welfare: increasing the local expenditure ratios and maximizing the economic contribution of the tourism for the hosting destination, 3)Employment Quality: increasing the wage and service quality without any discrimination on the race, gender, disability and elevating the local employment created by the tourism in quantity and quality, 4) Social Equality: Improving the opportunities, income and services provided for the poor and maintaining the fair distribution of the economic and social benefits created by tourism, 5) Satisfaction of the Tourists: Supplying a secure and satisfied experience to all tourists without any discrimination such as race, gender or disability and providing the continuity of the visits, 6) Local Control: Increasing the efficiency of the local administrations in the planning and resolution processes, providing the participation of the local population and supporting the development of tourism in different fields by providing consensus with the other stakeholders on the future and management of tourism, 7) Social Welfare: Protecting and improving the local life quality without causing any social deterioration or abuse, 8) Cultural Wealth: Respecting, protecting and strengthening the material and nonmaterial cultural values of the local residents, 9) Physical Integrity: Avoiding the deterioration of the environment quality by protecting the quality of the rural and urban areas, 10) Biological Variety. Protecting the natural areas, wild life and ecological balances and minimizing the deterioration, 11) Resource Productivity: Providing the productive usage of energy by efficient use of the renewable energy resources, productive and careful utilization of the scarce resources, 12) Environment Cleanup: Minimizing the production of any type of negative effect such as air, water, soil pollution and waste which can deteriorate the genuine beauty and environmental quality of the local area.

The application of the sustainable tourism can be realized by maintaining a) participation, b) coordination, c) representative democracy, d) legal infrastructure, e) cultural-social unity and the superiority of the public benefit, f) planning superiority (providing unity in super scale and subscale plans and abiding to the plans in land utilization resolutions) g) efficient and productive utilization of the renewable energy resources and supporting the usage of these resources (in buildings, industry, transportation, infrastructure, tourism plants etc.) h) recycling and waste management, i) competitiveness, $\mathrm{j}$ ) consciousness about nonconsumption, protection and environment, $\mathrm{k}$ ) sensitivity for continuing the local identity and genuine values. The realization of these targets requires the design of the tourism management policy based on the main references, support within the municipal organization and coordination with the other disciplines and cooperation. According to the World Tourism Organization, the sustainable tourism is: “....adopts the principle of satisfying the needs of the current tourists and hosting regions by paying regard for protection and development of the future opportunities. By this way, while the management of all resources and continuity of cultural unity, essential ecological processes, biological variety and life support systems are provided, the economic, social and esthetic 83 | P a g e 
requirements are put forward. Sustainable tourism products are the products coherent with the local environment, society and culture and create benefit rather than disturb by the touristic development". As a result, the need for protection and continuity of the natural and historical values by the sustainable tourism policies and in other words the need for nonconsumption of these values is underlined. The activities between production and consumption processes make the relation between environment, economy, tourism and administration a multi-dimensional process. Consumption practices can negatively affect the cultural elements defined by the related society throughout the history. The adoption of the nonconsumption consciousness by the individuals lies at the heart of sustainability concept. The consumption culture together with the components of the system affects the vision on the touristic values. This process requires the design of economy policies and environment prioritized tourism management map for the future of the human being and the other living beings on the earth. By this way, the emotion, behavior and thought of non-consumption, non-pollution and conservation can be adopted as a culture.

The municipalities, civil society organizations and the related societies are the key actors in revitalization and introduction of the genuine values reflecting the local identity, architecture and traditions. The selection of the resolution organs of the municipalities by the local society is coherent with the collectivism, democracy and participation principles of the tourism administration. The self-sustainable structure and efficient and productive utilization capacity of the municipalities matches with the sustainable tourism policies. One of the references of the policies on maintaining the balance between protection-utilization which is one of the main targets of tourism, is the legal responsibility of the local administrations on the designing the physical plans and protecting and developing the historical, cultural, environmental and civil values in accordance with the related residential areas.

City councils are the media for providing the awareness and discussions with efficient participation. Municipalities are responsible for the efficient and productive execution of the city councils. City councils are important instruments for adoption of the tourism as a life style in addition to the development of city vision and citizenship consciousness. The European Urban Charter (The European Declaration on Urban Rights) accepted by the European Council in 1992 is an important reference for the legislation regarding the citizen law. The Declaration underlying that the citizens deserve healthy environment, secure living area and sport, recreation, transportation, residence and commercial areas meeting the standards. The Declaration is also important as a document which highlights that it urges the municipalities to maintain the citizen law for an ecological tourism administration livable and coherent with nature and urges the citizens to recognize that they are the founders of the area they live (Keleş and Mengi, 2014: 33).

In accordance with the socio-economic and technological developments, the European Urban Charter II, 'Manifesto for a New Urbanity' was adopted by the Congress on the occasion of its 15th Plenary Session which support the European local administrations in constructing sustainable cities and towns. The Manifesto underlines the importance of the development of the civic ecology, decreasing the environmental footprints, protection of the natural resources, protection and enrichment of the biological variety, making the public values accessible by everyone and usage of the renewable energy. In addition to all these items, it advices to the local actors to construct residential areas which are attractive for the visitors and meet different demands, use a sustainable transportation policies which provide basic opportunities to visit the protected natural areas and compose transportation axes which are not dense and not sprawled. 'Manifesto for a New Urbanity' is router document for the application of the sustainable tourism principles and linking the protection principles with the sustainable tourism policies.

\section{Conclusion and Assessments}

Tourism, which is a significant opportunity for increasing competitiveness, becomes an important aim of development when it is integrated with sustainability and protectionism principles. The association of the tourism sector, which has developed all over the world with the globalization process, with the conservation policies and environment centered approaches is a crucial practice in terms of protecting universal values. However, this process has to be integrated with the management policies. Development of tourism sector without a rational and efficient management plan can create residence, transportation, infrastructure and parking problems and deterioration of physical-natural values and redundant sprawl of the residential areas. Local actors, through the entrepreneurial activities, have the duty and authority to avoid the extinction of the traditional production techniques and create trademarks which increase employment. The political decisions and administrative consciousness targeting the balance between 84 | $P$ a g e 
protection and utilization eliminate the negative effects of the tourism and provide economic and environmental advantages.

The tourism strategies which are supported by the environment-centered approaches and provide environmental sensitivity, offers development and protection balance with the tourism oriented development targets. It is possible to design solutions avoiding segregation in areas such as race, language, religion, disability, age by efficient and rational tourism plans. The land use decisions and applications with environment-centered point of view avoid spatial disaggregation and redundant sprawl. Even a tourism-oriented economic development can create residential, leisure, entertainment, infrastructure, transportation and parking problems even if it is not based on tourism plan. Accordingly, these problems deteriorate the historic fabric and environmental values which compose the city identity. It is obvious that ignorance of an integrated tourism administration plan causes the deterioration of the resources. The resolutions of the municipalities coordinated with the civil society organizations will raise the consciousness of the society. The environment based tourism administration plan and resolutions is the most important method for the protection of the ecological values and development of the tourism sector. The local actors should support the branding processes of the local employment opportunities as touristic elements. By this way, the genuine local production techniques can be integrated with the traditional structure and transmitted to the next generations and the natural values will be introduced to different cultures with the environment-centered approaches. The main role belongs to the local residents. A conscious society can maintain the sustainability of the tourism sector with the conscious policies.

\section{References}

Arslan, F. (2014). “The Tourısm Policy Of European Unıon and An Evaluation About Tourısm Strategy 2023 of Turkey". The Journal of International Social Research. 31 (7): 427-438.

Avcıkurt, C. (2007). Turizm Sosyolojisi: Turist-Yerel Halk Etkileşimi. Ankara: Detay Yayınları.

Çoban, A. (2002). “Çevreciliğin İdeolojik Unsurlarının Eklemlenmesi”. Ankara Üniversitesi SBF Dergisi. 57 (3): 3-30.

Çoruh, S. (1979). Turizm Ekonomisi. Ankara: Güven Matbaası.

Doğan, T. (2012). Turizm ve Çevre İlişkisi Bağlamında Ekoturizmin Çevre Üzerine Etkileri. Yayınlanmamış Uzmanlık Tezi, Ankara: Kültür ve Turizm Bakanlığı Dış İlişkiler ve Avrupa Birliği Koordinasyon Dairesi Başkanlığı.

Doğan, S., Yıldız, Z. (2007). "Bölgesel Kalkınma, Turizmin İlişkisi ve Göller Bölgesi Kalkınmasında Alternatif Turizm Potansiyelinin Kullanılabilirliğine Yönelik Bir Araştırma”. Süleyman Demirel Üniversitesi Sosyal Bilimler Enstitüsü Dergisi. 6: 147-181.

Doğanay, H. (2001). Türkiye Turizm Coğrafyası. Konya: Çizgi Kitabevi.

Eralp, Z. (1983). Genel Turizm. Ankara: Ankara Üniversitesi SBF Yayınları.

Gagnon Thompson, S. C. and Barton, M. A.(1994). "Ecocentric And Anthropocentric Attitudes Toward The Environment". Journal of Environmental Psychology. 14, 149-157.

Görmez, K., Değirmencioğlu, K.Ö. \& Bahçeci, H. I. (2012). "Türkiye'de Enerji ve Çevre Politikalar1: İnsan ve Doğa İlişkileri Açısından Bir Değerlendirme”, Kamu Politikalarında Dönüşüm KAYFOR 2012 Bildiriler Kitabı. (Ed. Bekir Parlak). Ankara: TODAİE, 723-737.

Gündüz, F. (2004). “Çevre ve Turizmin Sürdürülebilirliği”. Planlama. 1: 58-66.

İnceoğlu, S. (2005). “Türkiye: AB’nin Yetkileri Karşısında Nasıl Bir Egemenlik Anlayışı”. http://www.anayasa.gov.tr/files/pdf/anayasa_yargisi/anyarg22/sibel.pdf, Access Date: 19.12.2018.

85 | P a g e

www.iiste.org 
Kalabalık, H. (2011). İmar Hukuku Dersleri. 3. Baskı. Ankara: Seçkin Yayıncılık.

Karakuş, G. (2003). Avrupa Birliği Turizm Politikası. Ankara: Kültür ve Turizm Bakanlığ1.

Keleş, R., Mengi, A. (2014). İmar Hukukuna Giriş. Ankara: İmge Kitabevi.

Keleş, R. (2013). 100 Soruda Çevre: Çevre Sorunları ve Çevre Politikası. Genişletilmiş 2. Baskı. İzmir: Yakın Kitabevi.

Keleş, R., Hamamcı, C., Çoban, A. (2009). Çevre Politikası. 6. Baskı. Ankara: İmge Kitabevi.

Kılıç, S. (2013). Çevre Etiği. Ankara: Orion Kitabevi.

Kozak, M. (Ed.), (2014). Sürdürülebilir Turizm, Kavramlar-Uygulamalar. 1. Baskı. Ankara: Detay Yayıncilik.

Kozak Akoğlan, M., Evren, S., Çakır, O. (2013). “Tarihsel Süreç İçinde Turizm Paradigması”. Turizm Araştırmaları Dergisi. 24 (1): 7-22.

Kozak, N. (2012a). "Boş Zaman, Turizm ve Turist Kavramları". Genel Turizm Bilgisi. Ed. M. Akoğlan Kozak. Eskişehir: Anadolu Üniversitesi Yayınları. 2472: 2-18.

Kozak, N. (2012b). “Turizmin Toplumsal ve Fiziksel Çevre İlişkisi”. Genel Turizm Bilgisi. Ed. M. Akoğlan Kozak. Eskişehir: Anadolu Üniversitesi Yayınları. 2472: 109-123.

Mengi, A., Turan, A. M. (2016a). “Çevre-Merkezcilik”. Kentsel Planlama Ansiklopedik Sözlük. (Drl. M. Ersoy). 2. Baskı. İstanbul: Ninova Yayınları. 76-79.

Mengi, A., Turan, A. M. (2016b). “İnsan-Merkezcilik”. Kentsel Planlama Ansiklopedik Sözlük. (Drl. M. Ersoy). 2. Baskı. İstanbul: Ninova Yayınları. 169-170.

Meydan Yıldız, S. G. (2016). Çevre Bilinci ve Eko-Kent Planlaması: Gölbaşı Özel Çevre Koruma Bölgesi Örneği. Yayınlanmamış Doktora Tezi. Ankara: Ankara Üniversitesi Sosyal Bilimler Enstitüsü.

Padin, C. (2012). “A Sustainable Tourism Planning Model: Components And Relationships". Emerald Insight, 24: 510-518.

Pekin, F. (2011). Çözüm: Kültür Turizmi, Turizm ve Kültür Politikaları. 1. Baskı. İstanbul: İletişim Yayınlar1.

Sonuç, N. (2014). "Sürdürülebilir Turizm: Tanım ve İçeriği”. Sürdürülebilir Turizm, KavramlarUygulamalar. (Ed. M. Kozak). 1. Baskı. Ankara: Detay Yayıncılık, ss. 13-29.

http://library.atilim.edu.tr/shares/library/files/e-kitapTurizmi_2012-Ekitap.pdf., Access Date: 20.12.2018

http://www.unep.fr/shared/publications/pdf/DTIx0592xPA-TourismPolicyEN.pdf., Access Date: 20.12.2018

http://www.kalkinma.gov.tr, Access Date: 23.12.2018

http://www.oecd.org/industry/tourism/Tourism2016-Highlights_Web_Final.pdf, Access Date: 19.12.2018

https://ec.europa.eu/growth/sectors/tourism/offer_en, Access Date: 19.12.2018

86 | $P$ a g e

www.iiste.org 